\title{
Work on Capital Asset and Inventory Analysis
}

\author{
J. Pavithra ,Magdalene Peter, C.Kreethi Reddy
}

\begin{abstract}
Capital assets generally called unquestionable assets or property, plant and rigging, is a term used in speaking to assets and property that can just with noteworthy exertion be changed over into cash. This can be differentiated and current assets, for instance, cash or records, which are depicted commercial liquid assets. A great part of the time, simply generous assets are implied as fixed.
\end{abstract}

In addition, a fixed/non-current resource can likewise be characterized as an advantage not legitimately offered to a company's shoppers/end-clients. Capital resources are intended for use for a long time. The estimation of these benefits diminishes with their utilization or with time or numerous different reasons.

Stock is the most intemperate resources of an assembling organization. There is different stock control method, for example, Economic request amount, reorder point, security feed $A B C$ investigation, $X Y Z$ examination and so on. Without a moment to spare stock control, interminable stock control and some more. Stock choices legitimately influence the estimation of expense of products sold and subsequently assume a urgent job in deciding the detailed profit of an organization. Accordingly, an intensive investigation of stock valuation and related records can give a premise to surveying the budgetary position of a firm.

\section{Keywords : ABC investigation, , XYZ examination}

\section{INTRODUCTION}

Capital resources are the benefits held with the goal of being utilized on persistent premise adversary the reason for creating or demonstrating great or benefits and are not held for resale in the typical course of business. For instance land and building, plant and equipment, motor vehicles, furniture and establishments. A capital asset is a thing with a profitable life more significant than one uncovering period, and which outperforms a component's base capitalization limit. A fixed asset isn't purchased with the point of brisk resale, yet rather for profitable use inside the substance. A stock thing can't be seen as a fixed asset, since it is gotten with the desire for either trading it authentically or

Revised Manuscript Received on July 22, 2019.

Ms. J Pavithra Assistant Professor,Department of MBA,Bharath institute of Higher Education \& Research,Tamilnadu,India, Email: pavithralect@yahoo.com

Ms. Magdalene Peter ,Department of MBA,Bharath institute of Higher Education \& Research,Tamilnadu,India, Email: magdalene.bsb@gmail.com

C.Keerthi Reddy Studentr, Department of MBA,Bharath institute of Higher Education \& Research,Tamilnadu,India, Email:keerthi@gmail.com combining it into a thing that is then sold. Capital resources are at first recorded as resources, and are then subject to the accompanying general kinds of bookkeeping exchanges: Intermittent devaluation (for substantial resources) or amortization (for immaterial resources) Disability compose downs (if the estimation of an advantage decreases beneath its net book value) Attitude (when resources are discarded. In view of progressing devaluation, the net book estimation of a benefit is continually declining. In any case, it is conceivable under international financial reportin standards to revalue a fixed resource, with the goal that its net book worth can increment. [1],[3],[5]

. In this manner, a PC phone be viewed as a fixed resource (as long as its expense surpasses the capitalizationlimit). A capital resource is otherwise called Property, Plant, and Equipment.Valuation of capital resources is critical to have reasonable proportion of benefit or misfortune and money related position of the worry. Capital resources are intended for use for a long time. The estimation of these capital resources diminishes with their utilization or with time or numerous different reasons. A place of capital resources is decreased by utilization are changed over into money through charging devaluation. For right estimation of pay, legitimate administration of devaluation is basic, as deterioration ceaseless a piece of complete expense of creation.

\section{METHODOLOGY}

\section{A. METHODS OF DATA COLLECTION:}

PRIMARY DATA COLLECTION:

This investigation depends on the essential information. Essential information is the subtleties that is gathered physically, here in the fund division of CVEP (Ford) the procedure of confirmation is finished. We physically proceed to check whether the inventories are appropriately prepared for generation. Any deformities, issues, missing inventories will be noted for further explanation, after which it will be refreshed deliberately. [2 ],[4],[6]

This procedure is done essentially to:

O To guarantee that the supply of crude material and completed cooperative attitude stay consistent with the goal that procedure isn't going and requests of clients are properly met.

O To limit conveying cost of stock.

O To lessen the misfortunes of obsolesce and wastage and so on. 


\section{A Work On Capital Asset And Inventory Analysis}

O To limit stock requesting costs.

Auxiliary DATA COLLECTION:

Auxiliary information is gathered by the accessibility, it incorporates Inventory Data, Balance Sheet, Annual Reports, Books and Journals. What's more, some are gathered from the organization site.

\section{B. SAMPLING METHOD:}

This study is based on Convenience sampling method under theNon probability sampling technique. Capital assets generally called obvious assets or property, plant and rigging, is a term used in speaking to assets and property that can just with critical exertion be changed over into cash. This can be differentiated and current assets, for instance, cash or records, which are depicted commercial liquid assets. A significant part of the time, simply considerable assets are suggested as fixed

\section{RESULT \&DISCUSSION}

\section{Proportion ANALYSIS:}

Capital assets to Net Worth Ratio:

Capital advantages for total assets is a proportion that estimates the dissolvability of an organization. This proportion shows the degree to which the proprietors' money is solidified as capital resources, for example, property, plant, and gear, and the degree to which assets are accessible for the organization's activities (for example for working capital)

Total assets $=$ share capital + stores and surplus + held profit overal deficit.

Capital advantages for total assets proportion $=$ Net capital resources/Net worth[7], [9], [11]

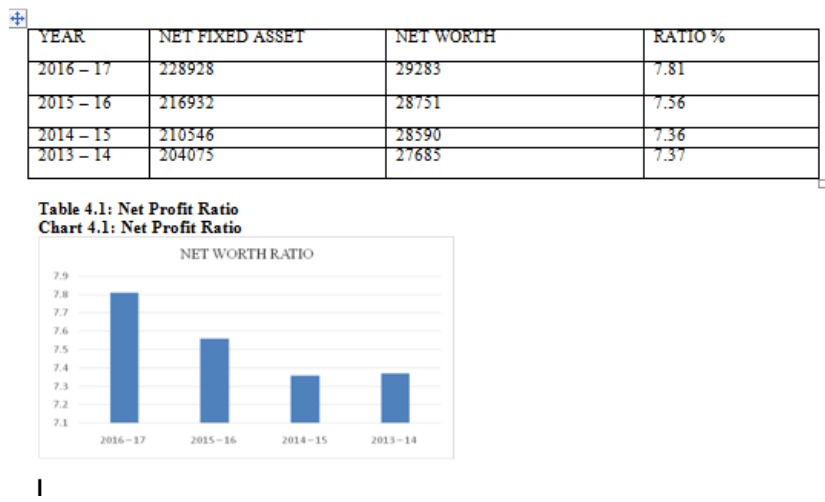

\section{Interpretation:}

The above table shows a continuous increase in Net worth and capital assets. In the year of 2016-17 net profit ratio is $7.81 \%$. This shows the satisfactory position of the company.

\section{Capital Asset Ratio:}

This ratio explains whether the firm has raised adequate long-term funds to meet its capital assets required and is calculated as under

Capital employed $=$ shareholders fund + Long-Term borrowings

Capital assets (after depreciation)

\section{Capital Employed}

This ratio gives an idea as to what part of the capital employed has been used in purchasing the capital assets for the concern. If the ratio is less than 1 it is good for the concern.

4 Table 4.2: Capital asset ratio
\begin{tabular}{|l|l|l|l|}
\hline YEAR & NET FIXED ASSET & CAPITAL EMIPLOYED & RATO \% \\
\hline $2016-17$ & 228928 & 147670 & 1.55 \\
\hline $2015-16$ & 216932 & 142589 & 1.52 \\
\hline $2014-15$ & 210932 & 142510 & 1.48 \\
\hline $2013-14$ & 204075 & 142085 & 1.44 \\
\hline
\end{tabular}

Chart 4.2: Capital asset ratio

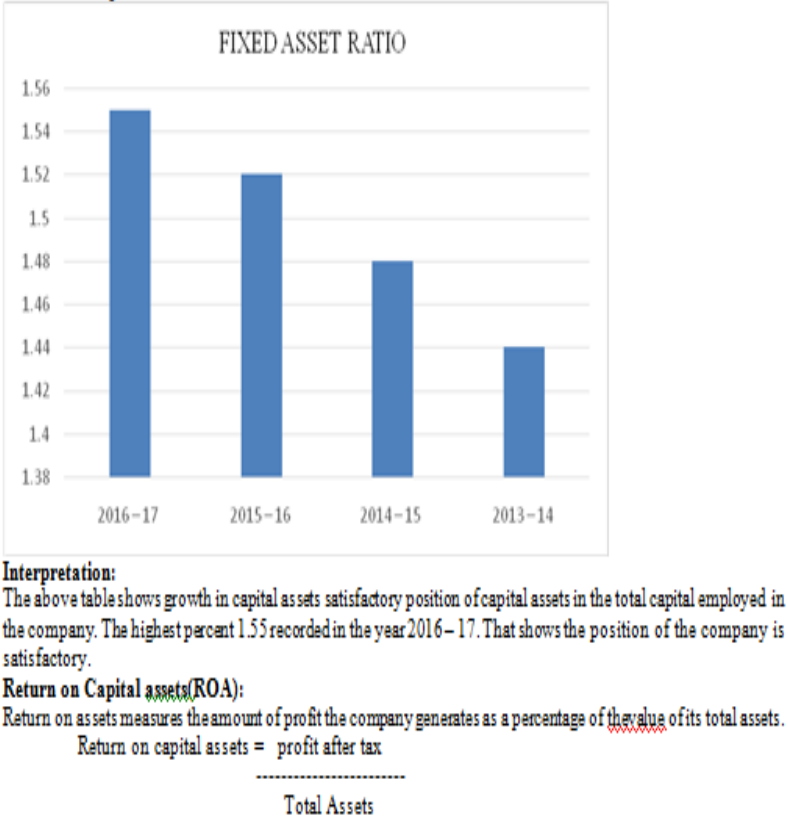

Table 4.3: Return on Capital asset
\begin{tabular}{|l|l|l|l|}
\hline YEAR & PROFIT AFIER TAX & TOIAL ASSEIS & RAIIO\% \\
\hline $2016-17$ & 4607 & 237951 & 0.019 \\
\hline $2015-16$ & 7371 & 224925 & 0.032 \\
\hline $2014-15$ & 1230 & 217931 & 5.6 \\
\hline $2013-14$ & 2451 & 211017 & 0.011 \\
\hline
\end{tabular}

Chart 4.3: Return on fixed asset

RETURN ON FIXED ASSET RATIO

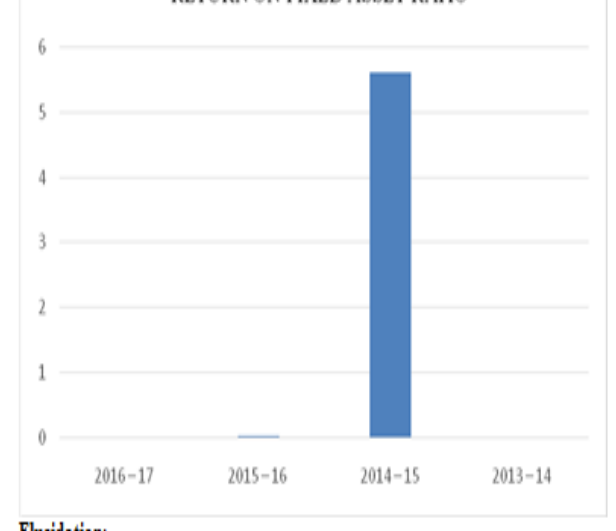

Elucidation:

Published By:

Blue Eyes Intelligence Engineering \& Sciences Publication 
Elucidation:

The above table shows increment in benefit during the year $2014-15$ is $5.6 \%$, yet in the year 2016-17 it has been diminished to $0.019 \%$. [8],[10],[12]

\section{Pattern Analysis:}

Pattern Analysis is planned for anticipating both present and future development of occasions through utilization of time arrangement information investigation which includes examination of information over a consecutive timeframe to recognize an example or pattern. It is utilized to extend the future bearing. This investigation is significant in the business and money related parts. Pattern investigation is frequently used to make projections and evaluations of money related wellbeing. Budgetary experts look at the past exhibition of their organization, alongside current money related conditions, to decide how their organization will perform later on. The general thought is that, all elements continuing as before, future patterns will pursue past execution. [31],[33]
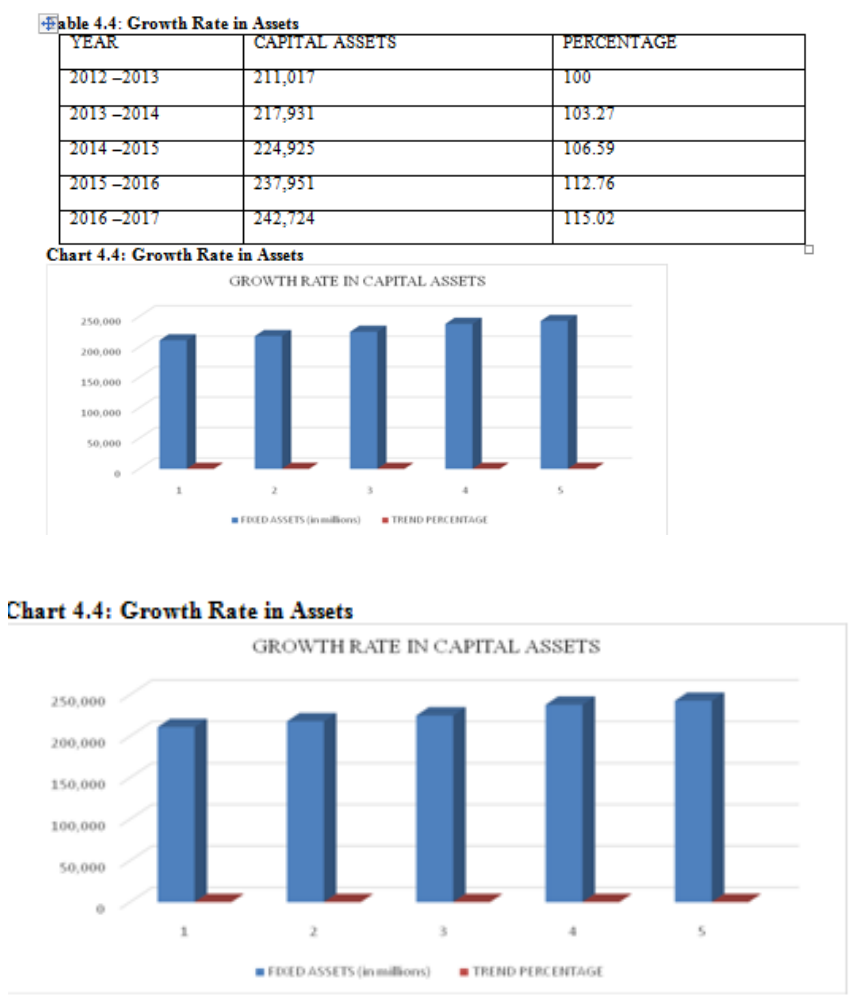

\section{Interpretation:}

The above table shows an increasing trend in the capital assets of the company. In the year 2016-17 it increased to $115.02 \%$. Which is a positive sign for the company, and if this continues the efficiency level will increase. [26],[28],[30]

Cycle Count:

Every inventory has its own code and address mentioned. This will help the company to identify and track that particular inventory. From the warehouse the materials are taken for kitting. After kitting it is then sent to assembly line. This physical count is then entered into the system and verification is done.

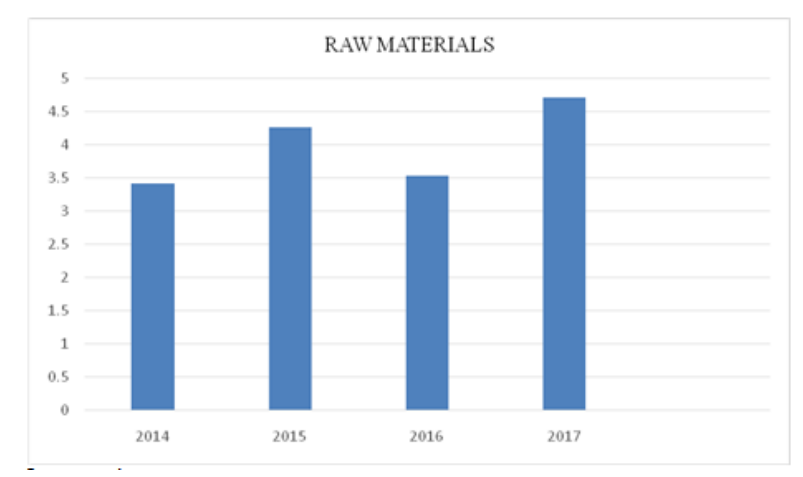

Table 4.5: Ram materials
\begin{tabular}{|l|l|l|}
\hline YEAR & AMIOUNI OPRAWMAIERAL & RAIIO (\%) \\
\hline 2014 & 3987 & $3.4 !$ \\
\hline 2015 & 4005 & 4.26 \\
\hline 2016 & 3843 & 3.53 \\
\hline 2017 & 4397 & $4.7 !$ \\
\hline Chart 4.5: Ram materials & \\
\hline Table 4.6: Finished Goods & \\
\hline YEAR & AMOONT OF FINISHED GOODS & RATID\%) \\
\hline 2013 & 5058 & 42.13 \\
\hline 2014 & 5022 & 41.85 \\
\hline 2015 & 5254 & 43.78 \\
\hline 2016 & 5943 & 49.52 \\
\hline 2017 & 6779 & 56.49 \\
\hline
\end{tabular}

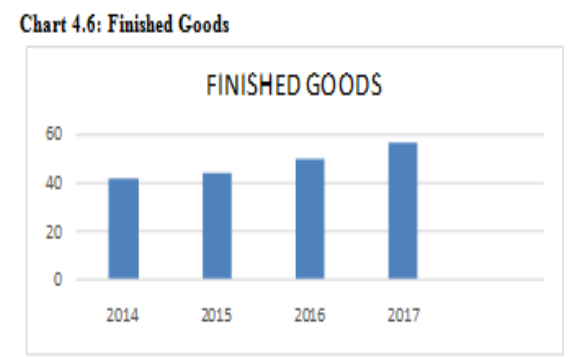

\section{FINDINGS:}

There is an expanding development in the benefits of the organization for as long as five years.

Capital resources the executives enables the organization to monitor all advantages. It can tell where the advantages are found, how they are utilized, and when changes were made to them. The information from the advantage the executives arrangement can guarantee that benefit recuperation will prompt better returns.

$\square$ Net worth proportion during the 5 years was in expanding pattern however in 2014-15 it has somewhat diminishes to $7.36 \%$.

$\square$ During the five years fixed resource proportion is in the expanding pattern, in 2016-17 it was $1.55 \%$. [25],[27],[29]

$\square$ Return on fixed resource is fluctuating during the previous five years, in 2014-15 it was 5.6\%, yet there was an enormous ruin to $0.032 \%$ in the year $2015-16$ and again it has been diminishes to $0.019 \%$ in $2016-17$.

$\square$ Growth rate in resource is in expanding point, in 2016-17 it was $115.02 \%$. 
$\square$ From the EOQ, the all out yearly expense of the organization during the years 2013-14 and 2015-16 where practically same while, the year $2014-15$ demonstrated a climb.

$\square$ During the five years completed great is in expanding point, in 2017 it was $56.49 \%$.[13], [15] ,[ 17]

\section{SUGGESTIONS}

$>$ Group fixed asset must be less than $\$ 100000$, of which life should be greater than 1 year.

$>$ Low cost fixes asset may be brought in bulk.

$>$ Special tools for vendors are actually owned by Ford that are at vendor's location are not verified henceperiodical verification can be done that will benefit in holding assets.

$>$ The EOQ calculated is suggesting that the company should obtain its inventory requirements by placing orders frequently to its suppliers.

$>$ The return on fixed asset of the company is below the standard ratio in all the five years, hence it should be improved at least to the standard.

$>$ The company needs to make some creative methods for efficient management by using its assets to generate earnings.

$>$ It is suggested to improve the position of the company by effective utilization of capital assets. [14],[ 16], [18]

\section{CONCLUSION}

When a benefit is bought and recorded, it is followed. All the capital resources are forever labeled with a fixed resource label that contains a sequential number. The number ought to relate to a log book or the fixed resource module (the backup record) of the bookkeeping framework.

Every capital resource's physical area is reported and any moves inside or outside the office are recorded. Any deals, new acquisitions, or rescues are additionally being recorded to guarantee repaired resource stock is to date. The general Company's fixed resource the board of the organization gives off an impression of being more than attractive. [19],[21],[23]

Stock administration must be accomplished for keeping precise records of merchandise that are prepared for creation. The organization gathers the cycle tally data and procedure it methodicallly to look after records. To know the genuine inventories that are accessible for production.Inventory the executives is significant for holding cost down, while meeting guideline. Free market activity is a fragile parity and this stock administration plans to guarantee that the equalization is undisturbed. [20],[22], [24]

\section{REFERENCES}

1) BharthVajan R., Ramachandran S.,Psychographic dimensions of training,2016,International Journal of Pharmacy and Technology,V-8,I-4,P-23727-23729

2) Balakrishnan P., Bharthvajan R.,A study on human resource planning in hospitals in Chennai City,2014,International Journal of Applied Engineering Research,V-9,I-22,P-7503-7507
3) Priyadarsini P., Bharthvajan R.,Role of emotional intelligence training programme in reducing the stress of the nurses,2014,International Journal of Applied Engineering Research,V-9,I-22,P-7411-7421

4) Kerinab Beenu G., Bharthvajan R.,Empirical analysis on the cosmetic buying behavior of young women in South India,2014,International Journal of Applied Engineering Research,V-9,I-22,P-7361-7366

5) Balakrishnan P., Bharthvajan R.,Whistling in the wind,2014,International Journal of Applied Engineering Research,V-9,I-22,P-7586-7593

6) Krishnan B., Peter M.,Health hazards of Indian Bpo employee-an alarming issue,2014,International Journal of Applied Engineering Research,V-9,I-22,P-7336-7341

7) Kerinab Beenu G.H., Peter M.,Role of insurance in economic development,2014,International Journal of Applied Engineering Research,V-9,I-22,P-7532-7539

8) Balakrishnan P., Peter M., Priyadarsini P.,Efficiency of safety measures for wellbeing of employees in manufacturing industry,2014,International Journal of Applied Engineering Research,V-9,I-22,P-7376-7382

9) Anbarasi M., Praveen Kumar S.,Online sales promotions of herbal products and its effectiveness towards tanisha.com,2019,Indian Journal of Public Health Research and Development,V-10,I-1,P-195-200

10) Anbarasi M., Praveen Kumar S.,Various online marketing and promotions strategies to improve the validation towards the organic products in the pharmaceutical sectors,2019,Indian Journal of Public Health Research and Development, V-10,I-1,P-263-269

11) Loganathan R., Praveen Kumar S.,Grievance handling a key factor for solving issues of employees in an organization,2014,International Journal of Applied Engineering Research,V-9,I-22,P-7483-7491

12) Loganathan R., Praveen Kumar S.,Study on preference of private label brands in super and Hypermarkets,2014,International Journal of Applied Engineering Research,V-9,I-22,P-7327-7335

13) Smitha M., Praveen Kumar S.,Understanding stress and its managementamong the nurses in Chennai city,2014,International Journal of Applied Engineering Research,V-9,I-22,P-7560-7565

14) Kerinab Beenu G.H., Praveen Kumar S.,A study on the investment behavior of Chennai investors in mutual fund schemes,2014,International Journal of Applied Engineering Research,V-9,I-22,P-7520-7525

15) Loganathan R., Praveen Kumar S.,Retention strategies key for organizational productivity,2014,International Journal of Applied Engineering Research,V-9,I-22,P-7443-7447

16) Pavithra J., Ganesan M., Brindha G.,State wise analysis of microfinance sector in India,2016,International Journal of Pharmacy and Technology,V-8,I-4,P-23417-23432

17) Pavithra J., Ganesan M.,A comparative study on microfinance in India and abroad,2016,International Journal of Applied Business and Economic Research,V-14,I-8,P-5471-5476

18) Pavithra J., Ganesan M.,A study on awareness and impact of micro-financial schemes,2016,International Journal of Applied Business and Economic Research,V-14,I-8,P-5449-5460

19) Senthilmurugan P., Pavithra J.,Consumer preference towards organised retailing with reference to Big Bazaar,2014,International Journal of Applied Engineering Research,V-9,I-22,P-7469-7475

20) Senthilmurugan P., Pavithra J.,Implication of social media marketing in growing healthcare industry,2014,International Journal of Applied Engineering Research,V-9,I-22,P-7448-7456

21) Loganathan R., Pavithra J.,Consumer perception towards private label brand over other brands in super markets and hypermarkets,2014,International Journal of Applied Engineering Research,V-9,I-22,P-7355-7360

22) Kerinab Beenu G., Pavithra J.,Tradeâ€"off between liquidity and profitability in logistics industry,2014,International Journal of Applied Engineering Research,V-9,I-22,P-7398-7401

23) Kerinab Beenu G., Pavithra J.,A study on the prospective consumerâ€ $\mathrm{TM}_{\mathrm{S}}$ perception towards utility cars in Chennai city,2014,International Journal of Applied Engineering Research,V-9,I-22,P-7526-7531

24) Pavithra J., Dilli Babu P., Ambuli T.V.,A study on budgetary control at Maruti Service Masters, Chennai,2014,International Journal of Applied Business and Economic Research,V-12,I-2,P-151-161

25) Pavithra J., Dilli Babu P., Ambuli T.V.,A study on customer satisfaction of retro Garments Pvt Ltd, Chennai,2014,International Journal of Applied Business and Economic Research,V-12,I-2,P-381-391

26) Kerinab Beenu G.H., Pavithra J., Senthilmurugan P.,A study on the influence of promotional activities for TATA ARIA among consumers in Chennai,2014,International Journal of Applied Engineering Research,V-9,I-22,P-7572-7578 
27) Vijayaragavan S.P.,An investigative expert that's general FBG sensors,International Journal of Mechanical Engineering and Technology,V-8,I-8,PP-1500-1505,Y-2017

28) Vijayaragavan S.P.,Equalization routing protocol for Wi-Fi sensor strategy,International Journal of Mechanical Engineering and Technology,V-8,I-8,PP-1662-1666,Y-2017

29) Karthik B., Kiran Kumar T.V.U., Vijayaragavan P., Bharath Kumaran E.,Design of a digital PLL using 0.35 $\hat{\mathrm{I}}^{1} / 4 \mathrm{~m}$ CMOS technology,Middle East Journal of Scientific Research,V-18,I-12,PP-1803-1806,Y-2013

30) Kanniga E., Selvaramarathnam K., Sundararajan M.,Kandigital bike operating system,Middle - East Journal of Scientific Research,V

31) Jasmin M., Vigneshwaran T., Beulah Hemalatha S.,Design of power aware on chip embedded memory based FSM encoding in FPGA,International Journal of Applied Engineering Research,V-10,I-2,PP-4487-4496,Y-2015

32) Jasmin M.,Optimization techniques for low power VLSI circuits,Middle East Journal of Scientific Research,V-20,I-9,PP-1082-1087,Y-2014

33) Jasmin M., Vigneswaran T.,Fuzzy controller for error control of on - Chip communication,2017 International Conference on Algorithms, Methodology, Models and Applications in Emerging Technologies, ICAMMAET 2017,V-2017-January,I-,PP-1-5,Y-2017

\section{AUTHORS PROFILE}

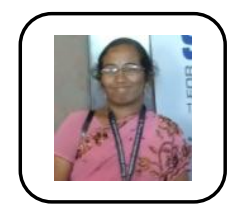

Ms. J Pavithra Assistant Professor, Department of MBA, Bharath institute of Higher Education \& Research,Tamilnadu,India

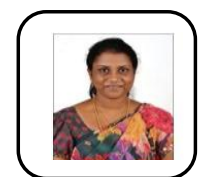

Magdalene Peter Assistant Professor,Department of MBA,Bharath institute of Higher Education \& Research,Tamilnadu,India

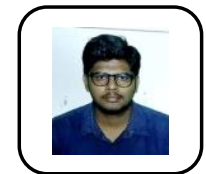

C.Kreethi Reddy Studentr ,Department of MBA,Bharath institute of Higher Education \& Research,Tamilnadu,India 